\title{
Infeksi Helicobacter Pylori di RSAB Harapan Kita
}

\author{
Eva J. Soelaeman, Budi Purnomo, Sukma W. Merati, Hartati N. Soehardjo, \\ Hadjat S. Digdowirogo
}

Infeksi Helicobacter pylori (HP) merupakan salah satu penyebab penyakit gastrointestinal pada anak yang gejalanya antara lain sakit perut berulang (SPB), dispepsia, muntah, hematemesis atau anoreksia. Pada sebagian besar pasien tersebut, penyebab terbanyak adalah HP. Oleh karena itu diagnosis HP sebaiknya dibuat sedini mungkin. Pengobatan HP pada dewasa masih kontroversial tetapi pada anak beberapa peneliti menganjurkan untuk memberikan pengobatan bila terdapat gejala.

Tujuan penelitian ini bertujuan untuk mengetahui angka kejadian HP di RSAB Harapan Kita, melaporkan gejala yang ditemukan, cara mendiagnosis, dan pengaruh pengobatan.

Hasil: Dari bulan Juli 2002 sampai dengan Juni 2003, telah dilakukan 42 endoskopi atas. Usia rata-rata 5 tahun 2 bulan ( 3 bulan - 16 tahun). Helicobacter pylori positif terdapat pada 23 pasien $(54,8 \%)$. Gejalanya adalah SPB $15(65,2 \%)$, muntah $6(26 \%)$, hematemesis $5(21,7 \%)$, dispepsia $5(21,7 \%)$ dan anoreksia $4(17,4 \%)$. Diagnosis endoskopi pada pasien HP positif adalah gastroduodenitis 12 (52,3\%), esofagogastroduodenitis $5(21,7 \%)$ esofagogastritis $5(21,7 \%)$ dan gastritis 1 pasien $(4,3 \%)$.

Dari pemeriksaan patologi anatomi (PA) ditemukan HP pada duodenum 17, antrum pylori 18, dan korpus gaster 9 pasien. Semua pasien diobati dengan terapi tripel (klaritromisin, amoksisilin dan omeperazol) selama 7 hari. Gejala menghilang pada 20 pasien $(87 \%)$. Sisanya masih menderita SPB, yang membaik dengan pemberian omeperazol selama 2 minggu.

Kesimpulan: Angka kejadian HP pada pasien kami 54,8\% dengan gejala yang paling sering SPB. H.pylori paling banyak ditemukan di antrum pilori dibandingkan duodenum atau korpus gaster. Dengan pengobatan gejala menghilang pada sebagian besar pasien.

Kata kunci: Helicobacter pylori, endoskopi, sakit perut berulang.

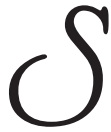
Cejak ditemukan pada tahun 1963, infeksi Helicobacter pylori ternyata terdapat pada hampir setengah penduduk dunia. ${ }^{1}$ Infeksi ini pada sebagian besar kasus sudah didapat sejak masa

\footnotetext{
Alamat Korespondensi:

Dr. Eva J. Soelaeman, Sp.A.

Rumah Sakit Anak \& Bunda (RSAB) Harapan Kita. Jl. S Parman. Grogol. Jakarta Barat.

Telepon: 021-740 1139. Fax.: 5601816.
}

kanak-kanak terutama di negara berkembang dan dapat menimbulkan gejala gastrointestinal. Gejala yang pernah dilaporkan adalah dispepsia, ulkus gaster/ duodenum ${ }^{2}$, sakit perut berulang, hematemesis, melena, muntah, perawakan pendek ${ }^{3}$, anoreksia. ${ }^{1}$ Karena itulah diagnosis HP harus dibuat sedini mungkin untuk mencegah infeksi kronik yang bisa mengganggu tumbuh kembang anak atau bisa menimbulkan kanker lambung. ${ }^{4}$

Pada dewasa, pengobatan terhadap HP masih kontroversial tetapi pada anak dianjurkan untuk 
diobati bila terdapat gejala karena setelah pengobatan sebagian besar gejala akan menghilang.

Tujuan penelitian ini untuk mengetahui angka kejadian HP pada pasien anak yang diarawat di RSAB Harapan Kita Jakarta, melaporkan gejala yang ditemukan, cara diagnosis dan dampak terapi.

\section{Subyek dan cara penelitian}

Penelitian ini bersifat retrospektif yang berlangsung dari bulan 1 Juli 2002 sampai dengan 30 Juni 2003. Semua pasien yang telah dilakukan endoskopi-atas dimasukkan ke dalam penelitian kecuali pasien yang mlenelan benda asing atau varises esofagus. Biopsi dilakukan di tiga tempat yaitu duodenum, antrum pilori dan korpus gaster. Bahan biopsi kemudian diwarnai dengan hematoksilin eosin dan giemsa. Semua pasien yang HP positif diobati dengan terapi tripel yaitu klaritromisin $15 \mathrm{mg} / \mathrm{KgBB} / \mathrm{hari}$, amoksilin $30 \mathrm{mg} / \mathrm{kgbb} / \mathrm{hari}$ dan omeperazol 0,6 mg/KgBB/hari. Setelah itu pasien diamati dengan mencatat apakah gejalanya menghilang atau tidak.

\section{Hasil}

Selama penelitian terdapat 42 pasien yang memenuhi kriteria. Umur rata-rata 5 tahun 2 bulan (3 bulan - 16 tahun). Helicobacter pylori ditemukan pada 23 pasien $(54,8 \%)$. Gejala yang paling sering ditemukan adalah SPB $(65,2 \%)$. Gejala lain adalah muntah, hematemesis, dispespsia dan anoreksia (Tabel 1).

Tabel 1. Gejala infeksi Helibacter pylori pada anak di RSAB Harapan Kita

\begin{tabular}{lll}
\hline Gejala klinis & \multicolumn{2}{c}{ Pasien } \\
\cline { 2 - 3 } & $\mathrm{n}$ & $\%$ \\
\hline Sakit perut berulang & 15 & 65,2 \\
Muntah & 6 & 26 \\
Hematemesis & 5 & 21,7 \\
Dispepsia & 5 & 21,7 \\
Anoreksia & 4 & 17,4 \\
\hline
\end{tabular}

Diagnosis berdasarkan endoskopi dan gambaran histopatologis dari 23 pasien yang HP positif adalah gastroduodenitis 12, esofagogastroduodenitis 5, esofagogastritis 5, dan gastritis 1 pasien. Nodul di duodenum terdapat pada 5 pasien.
Dari pemeriksaan patologi anatomi ditemukan HP di antrum pilori pada 18, duodenum 17, dan korpus gaster 9 pasien (Tabel 2).

Tabel 2. Gambaran histopatologi pasien Helicobacter pylori di RSAB Harapan Kita

\begin{tabular}{lll}
\hline Gambaran PA & \multicolumn{2}{c}{ Pasien } \\
\cline { 2 - 3 } & $\mathrm{n}$ & $\%$ \\
\hline Gastroduodenitis & 12 & 52,3 \\
Esofagogastroduodenitis & 5 & 21,7 \\
Esofagogastritis & 5 & 21,7 \\
Gastritis & 1 & 4,3 \\
\hline
\end{tabular}

Semua pasien HP positif diobati dengan terapi tripel selama 1 minggu. Setelah terapi gejala menghilang pada 20 pasien (87\%). Sedangkan pada 3 pasien masih tetap menderita SPB, namun kemudian gejala menghilang setelah pemberian omeperazol di lanjutkan selama 2 minggu.

\section{Diskusi}

Angka kejadian infeksi HP pada penelitian ini sebesar $54,8 \%$ sesuai dengan laporan di kepustakaan yaitu sekitar 40-70\%., ${ }^{2,3,5}$ Pada penelitian ini kami juga menemukan HP positif pada bayi di bawah 1 tahun; keadaan ini menunjukkan bahwa infeksi HP bisa terjadi pada usia sangat dini. Gejala yang paling sering ditemukan pada penelitian ini adalah SPB dan penemuan ini sesuai dengan laporan beberapa peneliti. ${ }^{4,5,6,7,9,10,11}$ Walaupun demikian tidak ada bukti bahwa HP merupakan penyebabnya; karena menurut laporan dari Parent dkk. ' Sakit perut tersebut lebih disebabkan oleh inflamasi yang terjadi dan hanya sebagai faktor pencetus. ${ }^{10,12,13} \mathrm{Hal}$ yang menarik dari penelitian ini adalah ditemukannya gejala hematemesis terutama pada pasien yang masih sangat muda ( usia kurang dari 1 tahun). Gejala ini belum pernah dilaporkan. Selain itu juga kami menemukan gejala anoreksia yang membaik setelah pengobatan.

Pada pasien yang HP positif ditemukan kelainan makroskopis seperti gastritis, esofagogastritis atau gastroduodenitis. Kami juga menemukan nodularitas di duodenum yang sesuai dengan laporan kepustakaan bahwa nodularitas tersebut merupakan tanda 
kolonisasi HP dengan densitas tinggi. ${ }^{14,15}$

Di RSAB Harapan Kita, biopsi diambil dari 3 tempat yaitu antrum pilori, duodenum, dan korpus gaster karena dengan cara ini angka positivitas HP yang didapat akan lebih tinggi sesuai dengan anjuran Megraud dkk. ${ }^{16}$ Kami juga menemukan HP hanya dari biopsi korpus gaster pada satu kasus.

Gejala menghilang pada sebagian besar pasien yang diberikan pengobatan. Di kepustakaan, hal ini masih diperdebatkan walaupun banyak peneliti yang menganjurkan pemberian pengobatan pada anak dengan gejala. ${ }^{17}$ Parent ${ }^{9}$ menduga bahwa nyeri perut yang terjadi pada anak dengan HP lebih disebabkan oleh inflamasi yang terjadi dan infeksi HP hanya sebagai faktor pencetus oleh karena itu dengan pengobatan gastritis, tidak ditemukan perbaikan.

Pada penelitian ini juga ditemukan 3 pasien yang tidak sembuh setelah pengobatan HP yang kemudian membaik setelah pemberian omeperazol selama 2 minggu, hal ini mungkin karena terjadi penyembuhan dari proses inflamasi. ${ }^{17,18,19}$

\section{Kesimpulan}

- Angka kejadian infeksi H.pylori di RSAB Harapan Kita adalah $54,8 \%$.

- Gejala yang paling sering ditemukan adalah skit perut berulang.

- Helicobacter pylori paling banyak ditemukan di antrum pilori.

- Pengobatan terhadap infeksi H.Pylori menghilangkan gejala pada sebagian besar pasien

Walaupun demikian untuk menilai perlunya pengobatan terhadap infeksi HP pada pasien anak yang mempunyai gejala perlu penelitian lebih lanjut dengan cara kasus kontrol buta ganda dan dengan jumlah pasien yang lebih banyak.

\section{Daftar Pustaka}

1. Neale,KR; Logan RP. The epidemiology and transmission of Helicobacter pylori infection in children. Aliment. Pharmacol. Ther. 1995; suppl.2:77-84.

2. Pounder, PE; The prevalence of helicobacter infection in different countries. Aliment Pharmacol Ther 1995; suppl.2:33-39.
3. TakahashiM, Kimura H, Watanabe K Helicobacter pylori infection in patients with idiopathic short stature. Ped Internat 2002; 44:277-280.

4. Torres, J; Perez-Rovez,G.; Goodman, KJ : A comprehensive review of the natural history of Helicobacter pylori infection in children. Arch Med Res 2000; 31:431-469.

5. Miyagi H, Azuma,T, ItoS. Helicobacter pylori infection occurs via close contact with infected individuals in early childhood. J Gastroenterol. Hepatol 2000; 15:257-262.

6. Cullen DJE, Collin BJ, Christiansen KJ, Epis J, dkk. When is Helicobacter pylori infection acquired ? Gut. 1993; 34:1681.

7. Ozen H, Dinler G, Helicobacter pylori infection and recurrent abdominal pain in Turkish children. Helicobacter 2001; 6:234-238.

8. Kupers EJ, Pena As, Van Kamp G, Lyterlinde AM dkk. Seroconversion for Helicobacter pylori. Lancet 1993; 342:328-331.

9. Parent F, Imbesi V, Moconi G. Effects of Helicobacter pylori eradication on gastric function indices in functional dyspepsia. A prospective control study. Scand J Gastroenterol 1998; 33:461-7.

10. Macarthur C, Saunders N, Feldman W. Helicobacter pylori gastro duodenal disease and recurrent abdominal pain in children. J A Med Asc. 1995; 273:729-34

11. Bujanover Y, Reif S, Yahov J, Helicobacter pylori and peptic disease in the pediatric patients. Pediatr Clin North Am 1996; 43:213-34.

12. Mitchel HM, Bohane TD, Tobos V. Helicobacter infection in children: potential clues to pathogenesis. J Ped Gastroenterol Nutr 1993; 16:120-5.

13. Gold B, Coletti, RB, Abbot M. Helicobacter infection in children. Recommendations for diagnosis and treatment. J Ped Gastroenterol Nutr. 2000; 31:490-7.

14. Soares Bahu MDG, Desilveira TR, Maugilnick I, Ulbrich Kulczyinski. Endoscopic nodular gastritis: an endoscopic indicator of high grade bacterial colonization and severe gastritis in children with Helicobacter Pylori. J. Ped. Gastroenterol. Nutr. 2003; 36:217-22.

15. Luzza F, Pensabebe L, Imeneo M. Antral nodularity identifies children infected with Helicobacter infection with high grade on gastric inflammation. Gastrointest Endosc. 2001; 53:60-4.

16. Megraud F. Diagnosis of Helicobacter infection. Scand J Gastroenterol 1996; 31 suppl 214:44-6.

17. Chang HY, Shana VK, Howey CV, Gold BD. Knowledge, attitude, and practice style of North American Gastroenterologist: Helicobacter pylori infection. J Pediatr Gastroenterol Nutr 2003; 36:235- 240.

18. Sherman P, Czinn S, Drumm B. Helicobacter pylori infection in children and adolescents: working group report of the first world congress of Pediatric Gastroenterology and Nutrition. J Gastroenterol Nutr 2002; 35:S128-33.

19. Heldenberg D, Wagner Y, Heldenberg E. The role of Helicobacter pylori infection in children with recurrent abdominal pain. Am J Gastroenterol 1995; 6:906-9. 